\title{
The Transfer Effect: A Critical Race Theory Examination of Black Male Transfer Student Athletes' Experiences
}

\author{
Joseph N. Cooper \\ University of Connecticut \\ Billy Hawkins \\ University of Georgia
}

\begin{abstract}
The purpose of this study was to examine the experiences of Black male student athletes who transferred from predominantly White institutions (PWIs) to a Historically Black College/University (HBCU) in the southeastern United States (U.S.). This qualitative case study involved a single focus group interview and two individual interviews with Black male transfer student athletes who were enrolled at a HBCU. Critical race theory (CRT) was applied as a theoretical framework to examine the impact of race and racism on the participants' experiences within different educational and sociocultural environments. The key research topics of interest included identifying the participants' reasons for transferring from a PWI to a HBCU and understanding their college experiences at the HBCU. Findings revealed participants' encounters with various forms of covert and overt racism at PWIs resulted in negative college experiences, which motivated them to transfer to a HBCU. Using tenets of CRT and a thematic analysis procedure, the following two emergent themes were identified: "We Were the Outcasts" and "They Want to See You Succeed." Implications for policy and practice are discussed.
\end{abstract}

Keywords: Black male student athletes, transfer student athletes, critical race theory, historically Black colleges and universities, intercollegiate athletics

A stated purpose of institutions of higher education in the United States (U.S.) is to provide quality educational experiences for its students and equip them with the skills necessary to be successful in careers after college (Pascarella \& Terenzini, 2005). In theory, this notion reflects the egalitarian U.S. values of equality, opportunity, and meritocracy. These institutions reflect such values by providing students from various backgrounds (e.g., socioeconomic, racial, cultural, etc.)

Cooper is with Educational Leadership, University of Connecticut, Storrs, CT. Hawkins is with the Kinesiology Department, University of Georgia, Athens, GA. Address author correspondence to Joseph Cooper at joseph.cooper@uconn.edu. 
with opportunities to earn advanced degrees, which have been found to increase an individual's likelihood of entering relatively high-status managerial, technical, and professional occupations with increased earnings and occupational stability (Pascarella \& Terenzini, 2005). These values also serve as foundational principles for the National Collegiate Athletic Association (NCAA) and its goal of enhancing the educational experiences of its student athletes through intercollegiate athletics. Specifically, the NCAA and its member institutions promote the idea that athletic participation contributes to positive developmental outcomes for student athletes in areas such as academic achievement, social engagement, leadership skills, persistence through graduation, and postcollege career mobility (Pascarella \& Terenzini, 2005; Potuto \& O'Hanlon, 2006; Shulman \& Bowen, 2001). However, upon deeper examination, several NCAA member institutions are failing to fulfill this purpose particularly as it relates to Black ${ }^{1}$ male student athletes. One indicator of this disconcerting reality is illustrated in the fact that since the NCAA began tracking graduation success rates (GSRs), academic success rates (ASRs), and academic progress rates (APRs), the data has revealed Black male student athletes consistently underperform compared with their student athlete counterparts (NCAA, 2011a, 2011b).

In an effort to address these disturbing trends, several scholars have examined factors related to Black male student athletes' academic performance (Comeaux \& Harrison, 2007; Harrison, Comeaux, and Plecha, 2006, Hildenbrand, Sanders, Leslie-Toogood, \& Benton, 2009; Martin, Harrison, \& Bukstein, 2010; Sellers, 1992), overall college experiences (Beamon, 2008; Lawrence, Harrison, \& Stone, 2009; Martin, Harrison, Stone, \& Lawrence, 2010; Oseguera, 2010), role identity development (Comeaux, 2010a; Harrison et al., 2009; Harrison, Sailes, Rotich, \& Bimper, 2011; Martin \& Harris, 2006), and perceptions of academic and athletic opportunities (Beamon \& Bell, 2006; Bimper, Harrison, \& Clark, 2012; Singer, 2005). Collectively, these studies documented various challenges Black male student athletes faced at postsecondary institutions based on their race, gender, and athletic status. Their experiences included encounters with negative stereotypes, feelings of social isolation, and a lack of institutional support (e.g., financially, academically, psychologically, etc.). In light of these challenges, many Black male student athletes also experienced adverse educational outcomes (e.g., lower levels of writing skills, reading comprehension, critical thinking, etc.; Pascarella et al. 1999). The revelation of such outcomes provided additional evidence to suggest that some institutions were failing to fulfill their stated purpose of enhancing student athletes' educational experiences through intercollegiate athletics.

More specifically, at many postsecondary institutions particularly major Division I predominantly White institutions (PWIs), the social, cultural, and academic climates have been found to be unfit for meeting the unique needs of Black students (Allen, 1992). Due to the sociohistorical foundations of PWIs in the U.S., institutional and cultural racism has been embedded within these institutions' structural arrangements (e.g., underrepresentation of ethnic minorities in leadership positions) and cultural practices (e.g., reliance on culturally-biased college entry exams for admission standards; Hawkins, 2010). Thus, to improve the campus climates at a majority of the postsecondary institutions in the U.S., it is imperative to understand how race and racism influence the experiences of marginalized student populations (e.g., Black male transfer student athletes). 


\section{Transfer Student Athletes}

Despite the abundance of research on Black student athletes at Division I PWIs, there is a scarcity of research on transfer student athletes in general (Keim \& Strickland, 2004; Kornspan \& Etzel, 2001) and even less on Black male transfer student athletes specifically (Harper, 2009). A transfer student athlete is a student athlete who meets the following criteria: 1) enrolled as a full-time student at either a two-year or a four-year institution for an academic term, 2) reported for practice or a game for a varsity athletic team at a two-year or four-year institution, and 3) transferred to another institution (NCAA, 2012a). Transfer student athletes accounted for $10 \%$ of the 4,433 Division I scholarships assigned in 2011 (Auerbach \& Prisbell, 2012). More specifically, transfer student athletes accounted for $12.8 \%$ of Division I football (7.7\% were two-year transfers and 5.1\% were four-year transfers) and $26.5 \%$ of men's basketball teams $(15.6 \%$ were two-year transfers and $10.9 \%$ were four-year transfers; NCAA, 2012b).

This growing trend of transfer student athletes was also highlighted in a recent NCAA (2013) report, which suggested $40 \%$ of men's basketball student athletes who started their college careers at one school would not remain at the same school through their second year. In fact, men's basketball student athletes transfer at a rate $36 \%$ higher than the general student population (Auerbach \& Prisbell, 2012). These transfer rates are particularly troubling because previous research has found that transfer student athletes are less likely to persist through graduation compared with nontransfer student athletes (Keim \& Strickland, 2004; Kornspan \& Etzel, 2001). For example, a recent NCAA (2012b) study of Division I schools found the APRs for two-year (926) and four-year (950) transfer student athletes was significantly lower than nontransfer student athletes (970). As a result, the NCAA has implemented several measures to dissuade student athletes particularly those in academically underperforming sports such as football and men's basketball from transferring (e.g., the one year-in-residence rule). Nonetheless, the aforementioned statistics suggest transfer student athletes may face unique challenges that hinder their progress toward degree attainment (NCAA, 2012a, 2013).

Furthermore, there is a conspicuous dearth of research on Black male transfer student athletes' experiences at postsecondary institutions in the U.S. (Harper, 2009). In an analysis of educational outcomes for Black male student athletes, Harper (2009) argued two-year institutions such as community colleges could greatly benefit from increasing the transfer rates of their Black male student athletes. The author cited several reasons why Black male student athletes attend these two-year institutions including academic remediation, limited financial resources, and/or an advantageous athletic opportunity. However, the author did not examine the perspectives and experiences of Black male transfer student athletes who attended these institutions and the factors that influenced their transfer decisions and subsequent educational outcomes. The current study seeks to address this gap.

One reason for the lack of research in this area is the fact that there is a limited amount of information about the transfer rates of specific subgroups beyond sport classifications (e.g., racial and gender trends; NCAA, 2012b; NCAA, 2013). However, it is clear that the two sports with the highest transfer rates, football and men's basketball, are also the two sports with the largest percentage of Black male student athletes (Auerbach \& Prisbell, 2012; NCAA, 2013). As such, these 
statistics coupled with the findings from the previous research on Black male student athletes' experiences at PWIs highlight the need for research on this subgroup of student athletes particularly understanding their reasons for transferring from these institutions to schools with different educational environments such as Historically Black Colleges/Universities (HBCUs). Beyond understanding their reasons for transferring from PWIs to HBCUs, it is also important to examine their subsequent educational experiences and outcomes at these institutions.

\section{Historically Black Colleges and Universities}

Before the passage of Brown v. Board of Education (1954) and the Civil Rights movement, HBCUs served as the primary source of education for Blacks (Allen \& Jewel, 2002). HBCUs are postsecondary institutions that were established during the midnineteenth to early twentieth century in the U.S. to provide educational opportunities for Black students during a time when they were denied access to White-controlled institutions (Gallien, 2005). The unique mission of HBCUs is to provide quality educational opportunities to students who may not otherwise have been able to attend a postsecondary institution due to social, financial, or academic barriers (Allen, 1992). Despite facing significant resistance from the dominant culture in the U.S., HBCUs continue to serve as purveyors of educational attainment and upward social mobility for Black students (Allen \& Jewel, 2002).

Moreover, many Black male student athletes choose to attend HBCUs to pursue their academic and athletic aspirations (Hodge, Bennett, \& Collins, 2013). The limited amount of research on Black male student athletes' experiences at HBCUs has found these institutions excel at cultivating nurturing environments through the establishment of comprehensive academic support systems, positive faculty-student interactions, and familial campus climates (Charlton, 2011; Cooper \& Hawkins, 2012). Given the unique role HBCUs fulfill as institutions of higher education, it is important to investigate how these institutional environments influence the educational experiences and outcomes for Black male student athletes. Therefore, the current study fills a gap in the literature by examining the experiences of Black male transfer student athletes who transferred from PWIs (both two-year and fouryear institutions) to a HBCU. In the next section, the authors will introduce the theoretical framework for the current study.

\section{Theoretical Framework: Critical Race Theory (CRT)}

During the mid-1970s, the emergence of the critical race theory (CRT) served as a response to the limited ability of critical legal studies (CLS) to address the effects of race and racism in the U.S. judicial system (Decuir \& Dixson, 2004; LadsonBillings \& Tate, 1995). The scholarship of Derrick Bell, Alan Freeman, and Richard Delgado initially led to the development of CRT within the legal system (Delgado $\&$ Stefanic, 2001). The premise of CRT is to examine the impact of race and racism on people of color in the U.S. and ultimately deconstruct the hegemonic system of White supremacy (Cook, 1995; Crenshaw, 1995; Dalton, 1995; Decuir \& Dixson, 2004; Matsuda, 1995). Ladson-Billings and Tate (1995) outlined three underlying principles of CRT: "1) Race is a major factor in perpetuation of the inequity in the 
U.S., 2) Property rights are the foundation of U.S. society, and 3) The intersection between race and property forms a critical perspective to understand social inequity" (p. 48). Expanding on these principles, CRT theorists established the following five CRT tenets: (a) (counter) storytelling (Decuir \& Dixson, 2004; Delgado \& Stefanic, 2001; Matsuda, 1995; Solórzano \& Yosso, 2002), (b) the permanence of racism (Bell, 1992; Lawrence, 1995), (c) the Whiteness as property norm (Harris, 1993), (d) interest convergence (Bell, 1980, 1992), and (e) the critique of liberalism (Crenshaw, 1995; Decuir \& Dixson, 2004; Taylor, Gillborn, \& Ladson-Billings, 2009).

(Counter) storytelling is a narrative method designed to challenge taken-forgranted meanings particularly beliefs, values, and norms associated with a dominant group (e.g., White Anglo-Saxon Protestants (WASPs) in the U.S.; Delgado \& Stefanic, 2001; Solórzano \& Yosso, 2002). The dominant narrative associated with Black male student athletes promotes a deficit perspective whereby their academic underachievement is primarily attributed to their individual inadequacies with little emphasis on the influence of environmental factors (Benson, 2000). In an effort to "counter deficit storytelling" and empower marginalized voices, the current study employed a CRT approach to focus on the experiences and perspectives of Black male transfer student athletes who attended a PWI and transferred to a HBCU (Solórzano \& Yosso, 2002, p. 23). These counter narratives provide valuable insight into understanding the impact of various institutional factors (e.g., formal policies and informal practices) and structural arrangements (e.g., the demographics of those in authoritative positions) that influence their educational outcomes.

Another tenet of CRT is the idea that racism is a permanent aspect of U.S. society (Bell, 1992). Within the U.S., endemic racism among postsecondary institutions has contributed to Black male student athletes' experiences with racial discrimination, social isolation, academic neglect, economic deprivation, and limited leadership opportunities (Cooper, 2012). The Whiteness as property norm refers to the social structure of the U.S. society, which grants Whites certain privileges on the basis of race (Decuir \& Dixson, 2004). The Whiteness as property norm operates in three primary forms: 1) the rights of disposition, 2) the rights of use and enjoyment, reputation, and status property, and 3) the absolute right to exclude (Harris, 1993). At PWIs, the fact that Whites fulfill a majority of the leadership positions on campus reflects the Whiteness as property norm as they determine the policies and subsequent enforcement as to which students have access to certain opportunities and resources (Singer, 2005).

The interest convergence tenet refers to the idea that any progress associated with a marginalized group is only accomplished insofar as it also benefits the dominant group (Decuir \& Dixson, 2004). Bell $(1980,1992)$ argued Black progress in the U.S. was primarily a result of fulfilling the economic needs of powerful Whites rather than altruistic desires to improve the plight of Blacks. The current overrepresentation of Black male student athletes in the NCAA's two largest revenue-generating sports of football and men's basketball constitutes a form of interest convergence (Donnor, 2005). Lastly, the critique of liberalism tenet refers to challenges against notions of colorblindness, legal neutrality, and incremental change (Decuir \& Dixson, 2004). CRT theorists contend that adherence to the colorblind ideology or beliefs of a postracial society undermine the critical examination of systemic racism, which is engrained in every facet of U.S. society. As a result, CRT serves as an applicable framework to examine the impact on race and 
racism within two U.S. social institutions of education and sport. More importantly, CRT provides a guide to deconstruct racist institutions, policies, and practices and construct new institutions of true equality (Ladson-Billings \& Tate, 1995).

The current study serves as a response to Singer's (2005) recommendation for sport management scholars to incorporate race-based epistemologies in the examination of sport-related phenomena such as Black male student athletes' experiences at institutions of higher education. In this vein, the current study builds on the work of previous scholars who have used CRT as an analytic tool to examine the influence of race and racism on the academic and athletic culture at postsecondary institutions in the U.S. and Black student athletes' experiences (Agyemang, Singer, \& DeLorme, 2010; Bimper et al., 2012; Comeaux, 2010b; Donnor, 2005; Harper, 2009; Singer, 2005, 2009; Singer, Harrison, \& Bukstein, 2010). Given the history of racism against Black males in the U.S. society and particularly in educational and sport settings (Cooper, 2012), CRT serves as an appropriate framework to analyze the impact of race and racism on the lived experiences of Black male transfer student athletes who attended a PWI and transferred to a HBCU. More specifically, CRT informed the development of the study, the analysis of data, and the presentation of the findings.

The purpose of this study was to examine the experiences of Black male student athletes who transferred from predominantly White institutions (PWIs) to a Historically Black College/University (HBCU) in the southeastern United States (U.S.). It is clear from the literature that race and racism continue to serve as mitigating factors in the experiences of Black male student athletes at PWIs (Beamon, 2008; Benson, 2000; Melendez, 2008; Singer, 2005, 2008, 2009). In contrast, research on Black male student athletes' experiences at HBCUs has revealed these institutions have excelled at cultivating positive educational environments for student athletes' holistic development (Charlton, 2011; Cooper \& Hawkins, 2012). However, it is less clear how the differences between the institutional environments influence Black male student athletes' positive experiences in college. Therefore, an analysis of Black male transfer student athletes' experiences in both types of institutional environments is beneficial for the identification of key institutional characteristics (e.g., sociocultural norms, faculty-student relationships, perceptions of institutional support, etc.) that facilitate positive educational outcomes. The current study incorporated CRT as an analytic tool to examine the experiences of Black male transfer student athletes' experiences at a PWI and a HBCU. The following research questions guided the current study:

1. What are the reasons Black male student athletes choose to transfer from a predominantly White institution to a Historically Black College/University?

2. How do Black male transfer student athletes make meaning of their college experiences at a Historically Black College/University?

\section{Methodology}

\section{Participants}

The data presented in the current study was extrapolated from a larger mixed methods exploratory study of 57 Black male student athletes' college experiences 
at a HBCU. Purposeful and criterion sampling approaches were employed to identify eligible participants (Patton, 2002). Purposeful sampling assisted in the identification of participants who could best address the research questions for the study. Criterion sampling was also incorporated to select a smaller sample of participants from the larger study to explore in-depth the participants' experiences as they related to the phenomena for the current study. Participants were selected on the following criteria: 1) self-identified as Black, 2) participated as a varsity football or men's basketball student athlete at a HBCU, 3) transferred from a PWI, and 4) currently enrolled at a HBCU. Participants $(N=5)$ for the current study included two football student athletes and three men's basketball student athletes. Demographic data of the participants is highlighted in Table 1.

Only Black male football and men's basketball student athletes were chosen for the current study for two primary reasons. First, Black male student athletes in these two sports have historically posted the lowest GSRs, ASRs, and APRs across all divisional classifications among all student athlete subgroups (NCAA, 2011a, 2011b). Therefore, investigating their experiences is pivotal to ascertaining a better understanding of how to improve their academic performance and persistence in college. Secondly, football and men's basketball generate the largest amount of revenues among all intercollegiate sports for institutions that sponsor athletic programs. Hence, the argument of athletic exploitation at these institutions has been primarily directed at athletes in these two sports (Hawkins, 2010). In an effort to understand how participants' involvement in these two sports influenced their academic experiences, it was important to recruit participants from these two sports. Moreover, the triangulation of findings across the two sports allowed the researcher to identify areas of convergence related to the participants' experiences in college. In addition, the criteria of transfer status from a PWI to a HBCU were employed because there is a conspicuous gap in the literature on this subgroup of student athletes.

\section{Data Collection}

This qualitative case study design investigated how participants, both individually and collectively, interpreted their lived experiences at a PWI and a HBCU (Patton, 2002). According to Patton (2002), cases can be "individuals, groups, neighborhoods, programs, organizations, cultures, regions, or nation-states" (p. 447). The

\section{Table 1 Participant Demographics}

\begin{tabular}{lllll}
\hline Participant $^{1}$ & Sport & Transfer School(s) & Classification & Major \\
\hline Brian & Basketball & JUCO PWI & Senior & Special Education \\
Daryl & Basketball & JUCO/NAIA PWI & Senior & Health and P.E. \\
Michael & Basketball & JUCO PWI & Senior & Health and P.E. \\
Paul & Football & D-I PWI & Freshman & Health and P.E. \\
Sean & Football & D-I PWI & Senior & Physical Therapy \\
\hline
\end{tabular}

${ }^{1}$ Pseudonyms were assigned to each participant by the researchers to protect their anonymity. 
case for the larger study was the examination of the institutional environment of a HBCU that was an active NCAA member institution. For the purpose of the current study, the cases under investigation were a group of Black male transfer student athletes. The researcher ${ }^{2}$ employed an "extreme case sampling" method, whereby the information rich cases (five Black male transfer student athletes) were selected due to their unique experiences as Black male student athletes who had attended a PWI and a HBCU (Patton, 2002, p. 230). The case study was also bounded by nature and time. The nature of this study was limited to the perceptions of five Black male transfer student athletes at one Division II HBCU. The time of the study was limited to a two-semester data collection period of contact between the researcher and the participants.

The two data collection methods for the current study included a single semistructured focus group and two semistructured individual interviews. Focus groups are a useful data collection tool to gather rich data on the collective experiences of a group of individuals related to a specific phenomenon (Roulston, 2010). In addition, focus groups are particularly beneficial for understanding the prevalence and influence of cultural values and group norms (Kitzinger, 1995). For example, the dialectic structure of focus groups allows the researcher to examine multiple forms of communication including "day to day interaction, including jokes, anecdotes, teasing, and arguing" (Kitzinger, 1995, p. 299). Another primary form of data collection for the current study was the use of individual interviews. These types of inquiry are particularly effective for ascertaining detailed information about the lived experiences of certain individuals (Denzin \& Lincoln, 2005). Furthermore, the semistructured nature of both interviews allowed the researcher to address the primary topics of interest for the study as well as to probe participants for elucidation regarding their experiences (Roulston, 2010). The two individual interviews were conducted with two focus group participants who participated in a single interview. All five participants were solicited for individual interviews, but due to participants' availability, only two participants were able to take part in the individual interviews.

The researcher also incorporated measures to enhance the quality and credibility of the qualitative findings including the writing a subjectivity statement, data and methodological triangulation, and member checks (Denzin \& Lincoln, 2005; Patton, 2002; Roulston, 2010). The researcher's detailed subjectivity statement allowed the researcher to critically examine his assumptions and perspectives before and throughout the research process (Roulston, 2010). This reflexive practice enhanced the transparency of the research process by allowing the researcher to understand and convey to the reader how his background relates to the study as well as how this connection may be theorized in a manner consistent with his "epistemological and theoretical assumptions about knowledge" (Roulston, 2010, p. 127). For example, the researcher acknowledged through his subjectivity statement his unique positionality (e.g., Black male, former athlete, teacher, mentor, and researcher) to the study and key assumptions he possessed before and throughout the research process. Likewise, these aforementioned subjectivities also provided the researcher with a level of credibility among the participants in the study because they felt a sense of connection with him because of their commonalities (e.g., race, ethnicity, gender, and athletic backgrounds) and comfortable sharing their personal experiences (Singer, 2005). The fact that the researcher did not work at the institution, 
but spent eight months in the field also enhanced the participants' familiarity and trust with the researcher that reported findings would not adversely affect their status at the school.

In addition to the subjectivity statement, the researcher employed data and methodological triangulation and member checks to enhance the quality of the study and ensure accuracy in data analysis and the presentation of findings (Denzin \& Lincoln, 2005; Patton, 2002). Denzin and Lincoln (2005) defined triangulation as a multimethod approach used by a researcher to achieve better or more accurate results. Data triangulation occurred through the inclusion of student athletes from two different sports (Patton, 2002). Therefore, the experiences of the football and men's basketball student athletes were examined for areas of convergence as well as divergence. Methodological triangulation was accomplished using two data collection methods (focus group and two individual interviews; Patton, 2002). In addition, member checks were solicited both during and after the data collection process to ensure the researcher's transcriptions and interpretations of the data were consistent with the participants' intentions (Roulston, 2010). Each participant was sent a copy of the completed transcripts and final analyses. Based on the feedback, edits were performed to enhance the accuracy of the reported findings.

\section{Data Analysis}

Using CRT as an analytic tool, a thematic analysis of the qualitative data was performed to examine the data for emergent themes related to the two research questions for the study (Biddle, Markland, Gilbourne, Chatzisarantis, \& Sparkes, 2001; Gratton \& Jones, 2010; Patton, 2002; Scanlan, Ravizza, \& Stein, 1989; Scanlan, Stein, \& Ravizza, 1991). The following four CRT tenets were incorporated in the thematic analysis of this study: a) interest convergence, b) the permanence of racism, c) the Whiteness as property norm, and d) (counter)storytelling. A thematic analysis incorporates aspects of an inductive content analysis, whereby data are examined through a systematic process to identify key concepts and patterns in the data (Scanlan et al., 1989). The thematic analysis used in this study included four analytical stages: 1) open coding, 2) axial coding, 3) comparative coding, and 4) selective coding (Biddle et al., 2001; Gratton \& Jones, 2010; Patton, 2002; Scanlan et al., 1989; Scanlan et al., 1991).

The open coding process involved a line-by-line analysis of the interview transcripts resulting in a comprehensive list of codes from the participants' responses (Gratton \& Jones, 2010). All open codes were conceptualized by the participants' exact words, which is also known as in vivo coding (Martin et al., 2010; Ryan \& Bernard, 2000). At this phase, the researcher also quantized the data by charting the frequencies of open codes within each transcript to identify the salience of initial themes (Tashakkori \& Teddlie, 1998). Quantizing qualitative data is a useful technique to ensure emergent themes are substantiated by participants' response patterns (Tashakkori \& Teddlie, 1998). Next, the axial coding process involved the organization of related open codes into smaller clusters. This process involved the following reductions: a) focus group (387 open codes to 57 axial codes); b) individual interview one (295 open codes to 25 axial codes); c) individual interview two (162 open codes to 19 axial codes). 
The comparative coding process involved the cross-referencing of axial code patterns across data sets. At this point, clusters of axial codes across data sets were merged together based on relevance. This process reduced the 101 axial codes across data sets to 36 comparative codes. The selective/thematic coding process incorporated the four tenets from CRT to elucidate the emergent themes. From this process, the 36 comparative codes were reduced to six emergent subthemes, which were then organized into two overarching themes as they related to each research question. The aforementioned themes are presented in the results section.

\section{Results}

The presented results from this study highlight the salience of the four CRT tenets (interest convergence, the permanence of racism, the Whiteness as property norm, and (counter)storytelling) as they related to Black male transfer student athletes' experiences at PWIs and a HBCU. A primary aim of CRT is to capture the experiences and empower the voices of people of color who have been historically marginalized. Both the focus group and individual interview methods provided the Black male transfer student athletes with an opportunity to express their lived experiences in two different sociocultural and educational environments. The two primary probes for the current study included identifying the reasons why Black male student athletes chose to transfer from a PWI to a HBCU and understanding how they make meaning of their college experiences at a HBCU. A thematic analysis of the data revealed the following two emergent themes: "We Were the Outcasts" and "They Want to See You Succeed."

\section{"We Were the Outcasts"}

The first research question of the current study focused on identifying Black male student athletes' reasons for choosing to transfer from a PWI to a HBCU. The emergent theme of "We Were the Outcasts" refers to the participants' lack of social connection with their faculty, administrators, staff, and peers at the PWIs they previously attended. More specifically, the CRT tenets of interest convergence, the permanence of racism, and the Whiteness as property norm serve as useful lenses to interpret the participants' experiences at these institutions.

Interest Convergence at PWIs. Using the CRT tenet of interest convergence, participants' responses about their experiences at PWIs highlighted the fact that a majority of the Black students at these institutions were athletes. This disparate enrollment of Black student athletes compared with Black student nonathletes reflected the interest convergence between these PWIs and Black male student athletes. Specifically, the interest of these PWIs involved their desire to field successful athletic programs, thus justifying their need to recruit talented Black student athletes rather than a large number of Black student nonathletes for nonathletic reasons (e.g., academic merit, diversity inclusion, etc.). This interest converged with Black male student athletes' interest in pursuing an opportunity to gain a college education and participate in intercollegiate athletics. $\mathrm{Brian}^{3}$, a 
fourth year basketball player who transferred from a junior college (JUCO) $)^{4} \mathrm{PWI}$, explained how the lack of Black student enrollment at the PWI affected his overall experiences:

I transferred from Pine Lake College ${ }^{5}$ [JUCO school]...It's like population like 1,500, but it's predominantly white and a small-time country town...you actually feel like out of place really...So, it [the men's basketball program] was like a first-year program and we were there. So, it was new to them [the predominantly White campus community]. So, it was like we were the outcasts of the group. Everyone knew who we were. Wherever we went, we were the basketball team.

Brian described how before the addition of the basketball program at the JUCO PWI the institution did not enroll a large number of Black students. Brian's observations of the demographic make-up of the institution signaled to him that the primary reason he and his teammates were admitted to the school was based on their athletic ability. In his individual interview, Brian elaborated on how he felt the PWI primarily valued him and his Black teammates athletically:

Yeah...the faculty and staff, the teachers, the students. It was like when we first got there it was like, “I don't want y'all there." You know what I'm saying. My first year was kind of bumpy. We had a 17-13 record and they [faculty, staff, and students] didn't like us. And my second year we won the conference. We started off like 10-0. And, then, it started changing. Kind of like Glory Road.

Brian compared his experiences at the PWI to the film Glory Road, which documented the journey of the first all-Black starting five to win a NCAA men's basketball national championship in 1966 when the Texas Western Miners defeated Adolph Rupp's all-White Kentucky Wildcats team. In the film, the Black basketball players were alienated when they first arrived on campus and it was not until they started winning games that the faculty, staff, and students at the school viewed them with any favor. Brian's analogy reiterates the interest convergence between many PWIs and Black male student athletes which centers around their athletic abilities rather than other aspects of their identities (e.g., academic prowess, personal creativity, etc.).

Furthermore, Michael, a fourth year basketball player who transferred from another JUCO PWI, also observed this trend of Black male overrepresentation on athletic teams and underrepresentation in the general study population:

Really, the basketball team was the only black people that was at school and that was it...after practice it was just go home. It wasn't like you had some kind of bond with the other students at school or whatever. But, it was just it was like that.

The low Black student enrollment indicated to the participants that the PWI's interest in them was primarily based on their athletic abilities. Given the high visibility and financial benefits associated with fielding successful athletic teams, many institutions view the recruitment of talented Black male student athletes as a transactional relationship. Within this relationship, Black male student athletes receive the opportunity to participate in intercollegiate athletics, and in exchange, 
these institutions generate athletic revenue with little to no concern of cultivating positive educational environments for Black male student athletes to develop and thrive holistically.

Permanence of Racism at PWIs. As a marginalized group at the PWIs, participants described various incidents of covert racism, which motivated them to transfer from a PWI to a HBCU. For example, Daryl, a fourth year basketball player who attended a JUCO PWI and a National Association for Intercollegiate Athletics (NAIA) PWI before enrolling at a Southern State University ${ }^{6}$ SSU; HBCU), explained how he felt race played a role in the treatment he and his teammates received on campus:

And it's different, because to me I felt like we were the best team on campus. And knowing that the majority of the teams were White, and the students were White, they pretty much didn't like that. Because that kind of felt weird in a certain way. I just always had a different vibe like every time I go back to that school.

Daryl's comments revealed how he felt the predominantly White campus community viewed the success of the predominantly Black men's basketball with disdain because of their race. Brian described an incident where he and his Black teammates experienced avoidant behavior from their peers at the PWI he attended:

$[\mathrm{O}]$ ne time, it was after a basketball game. And we had went to this party. And it was like, we went as a team, you know, we all go together. And when we walked in and it was like, "Oh, there go the basketball team," you know what I'm saying. And the party just got. . . it wasn't the same vibe as it was before we walked in.

This level of cultural mistrust was reflective of a trend among many Black male student athletes' experiences at PWIs due to the lack of positive interactions with the campus community (Melendez, 2008; Singer, 2005). Along the same lines, Paul, a first year football player who transferred from a major Division I PWI, explained how he perceived the differential treatment from his professors as a form of covert racism:

Like I went to a White school. I went to Promenade [a major Division I PWI] before I came here. Like if you were to tell a professor a reason why you missed the test or a reason why you didn't pass, or anything like that, they're just going to look at it as an excuse because they don't really understand where you came from and the situations you deal with. But, if you tell the teacher here [the HBCU] something like that most likely they know you don't just do it all the time. Like, they pretty much understand where you're coming from.

Paul interpreted the actions of his professors at the PWI as a form differential treatment because of his race and athletic status, whereas at the HBCU he felt his professors treated him like any other student. Regardless of the professor's intentions at the PWI, the cumulative impact of the Paul's negative experiences at the institution conditioned him to perceive acts of differential treatment as a form of covert racism. 
Whiteness as Property Norm at PWIs. Participants also highlighted their encounters with overt racism. Brian described an experience where he and his teammates were blatantly treated differently from their White peers:

We were in the student center one day...we brought the X-Boxes and we were playing. They told us to turn it off because we were playing NBA2K [sport video game]. But the next day like a group of Caucasian guys were in there playing Call of Duty [violent action video game], and there was no problem. There was no problem with it. A couple of incidents like that.

In this incident, Brian perceived the treatment he and his teammates received as unfair because the White students were granted certain privileges that they were denied. He attributed this differential treatment to race. In particular, the administrator demonstrated the Whiteness as property norm by regulating Brian and his teammate's usage of the student center amenities. The fact that Brian's White classmates were able to use the amenities that he and his teammates were not allowed to use signaled to them that they did not possess the same privileges as their White counterparts.

Overall, the participants' motivation for choosing to transfer from a PWI to a HBCU was related to the lack of perceived fit between the PWI they were enrolled and their sociocultural backgrounds. More specifically, these institutions failed to meet their unique needs (e.g., expressed acceptance of and appreciation for their cultural backgrounds) as minority students. This lack of perceived fit was reflected in the low Black student enrollment, the prevalence of negative stereotypes associated with Black male student athletes, and the differential treatment they experienced from the faculty, staff, and peers. Collectively, the participants' negative encounters at these PWIs created feelings of isolation, resentment, and frustration, which motivated them to transfer to a HBCU.

\section{"They Want to See You Succeed"}

The second research question of the current study focused on understanding how Black male transfer student athletes made meaning of their college experiences at a HBCU. Using the CRT tenet of (counter) storytelling, the participants' experiences at the HBCU they attended provided an alternative perspective to the dominant narrative of HBCUs as ineffective educational institutions (Riley, 2010). The most salient theme identified regarding the participants' responses about their college experiences was the theme, "They Want to See You Succeed." This theme captured how the participants perceived the educational environment at SSU to be accepting and supportive of their holistic development and well-being.

(Counter)stories of Faculty Assistance at a HBCU. The participants cited their professors as the most influential group in the cultivation of the positive educational environment at SSU. Daryl explained how his professors at SSU displayed a sincere interest in his overall development compared with the professors at his previous two schools:

$[\mathrm{M}] \mathrm{y}$ professors, they're willing to work with you. They know that you have a real busy schedule...they're willing to take the time out to get with you the information that you missed...So, that's one thing I can say that since I've been at my other two schools [PWIs] I haven't had. 
From Daryl's experiences, his professors at SSU did not penalize him because of his athletic commitments unlike the previous PWIs he attended. They accommodated his athletic schedule and provided him with opportunities to retrieve information and complete assignments he missed while out of class.

In addition to understanding the participants' athletic schedules, the professors at SSU also maintained high expectations for them as students. Brian described how the professors at SSU demanded excellence out of him:

I mean they know you're an athlete, but they try to push you to be more than just being an athlete. Like they are not going to let you just settle for, "I'm an athlete,". . . It's like, you're going to be athlete, and you're going to get your work done at the same time. So, it's pretty much hands on. And you can reach them at any time you want.

Brian's comments reflect the transformational nature of the educational experience provided by HBCUs, whereby faculty and staff engage in an ethic of care regarding students' overall well-being. The professors' nurturing attitudes reflected one of the founding principles of HBCUs, which is to provide Black students with the support they need to develop regardless of the challenges they may face individually (e.g., time constraints, academic preparedness, etc.; Allen \& Jewel, 2002).

(Counter)stories of Faculty Interest at a HBCU. Participants also discussed how being able to talk with their professors about nonacademic related issues was particularly beneficial for them in their transition to college. Paul poignantly described how his relationships with his professors at SSU extended beyond academic-related issues:

It's like when we say they understand us, they really do, because...basically, all of the teachers that I've had graduated from Southern State [SSU], so they really do understand where we're coming from. You can talk with them about whatever. Like if something happened with your life or some situation you're going through, a lot of them will talk to you about that other than just class.

As SSU alumni, Paul's professors could not only relate to his experiences as a SSU student, but also more importantly, they were heavily invested in his success both during and after college. The professors' willingness to talk with him about issues aside from his academic performance indicated to him they cared about his overall well-being. The participants' positive relationships with their professors led to increased levels of academic engagement and self-efficacy. Michael captured the participants' feelings about the difference between their interactions with the professors at PWIs compared with the HBCU:

At the JUCO [PWI], it was more just after class that's it. She's gone. He's gone. That's it. You really got to catch them when you can. But at the HBCU, it's more of "Did anybody have questions. You come talk to me after class. I can give you my number. Give me e-mail address. Please feel free to talk to me. I'm trying to help you out." It's more like they want to see you succeed, and they want to see you do better in academics and just as a person in general. 
At no point in the interviews did any participant cite having a positive relationship with their professors at the PWIs they previously attended. However, when referencing their experiences at SSU, they described how their professors affirmed their self-worth as holistic individuals through displayed actions of care.

(Counter)stories of Campus Climate at a HBCU. In addition to their positive relationships with professors, the participants also highlighted how the overall environment at SSU contributed to their positive experiences in college. Sean, a senior football player who transferred from a mid-major Division I PWI, described how the culture at SSU made his college experience enjoyable:

Basically, I'm glad I made the decision to come here. Class has been great. I've had a high GPA ever since I've been in school. Like he said the social life here makes stuff go by faster, you know. You've got something outside football, or basketball, or class like something else you can get your mind off of everything. So I'm pretty good with that.

Since their inception, HBCUs have served as familial environments committed to nurturing positive developmental outcomes for Black students (Allen \& Jewel, 2002). Sean's experiences at SSU reflect the unique role HBCUs fulfill in terms of creating culturally congruent environments for Black students to thrive. All the participants cited being around peers from similar backgrounds and peers who they could identify with socially and culturally contributed to their positive experiences at SSU. These positive relationships affirmed to them that they made the right decision to transfer to a HBCU.

On a whole, the participants expressed positive feelings about their decision to transfer from a PWI to a HBCU. The most significant difference in terms of their experiences at a PWI and a HBCU was the quality of their relationships with their professors. At the PWIs, the participants felt the professors were unapproachable and apathetic toward them. Yet, at a HBCU, the professors expressed a sincere interest in their well-being and personal development. The professors demonstrated this ethic of care through various actions such as accommodating their athletic schedules, making themselves accessible outside of class, and talking with the participants about non-academic-related issues. Likewise, the social environment at SSU consisted of students from similar backgrounds, which increased the participants' sense of belonging and connection to the institution.

\section{Discussion}

The purpose of this study was to examine the experiences of Black male student athletes who transferred from predominantly White institutions (PWIs) to a Historically Black College/University (HBCU) in the southeastern United States (U.S.). Specifically, the guiding research questions focused on identifying Black male student athletes' reasons for transferring from a PWI to a HBCU and understanding the nature of their college experiences at the HBCU. The use of a focus group and individual interviews provided an opportunity for participants to share their experiences both collectively and individually. CRT was incorporated as an analytic tool to examine the nature, extent, and influence of race and racism on Black male transfer student athletes' experiences at a PWI and a HBCU (Ladson-Billings \& 
Tate, 1995). Explicitly, the following CRT tenets were applied to the current study: 1) interest convergence, 2) the permanence of racism, 3) the Whiteness as property norm, and 4) (counter)storytelling. Within this section, the authors will explain how each of the aforementioned tenets related to the emergent themes and provide implications for policy and practice.

The first research question of this study focused on identifying and understanding Black male transfer student athletes' reasons for transferring from a PWI to a HBCU. The emergent theme of "We Were the Outcasts" captured the participants" negative feelings about their experiences at the PWIs they attended before transferring to a HBCU. A major factor that contributed to the participants' social isolation at these institutions was the conspicuously low Black student enrollment. Participants highlighted how the majority of the Black students at these PWIs were athletes. Brian captured the group consensus on the impact of these disparate enrollment trends at PWIs on their college experiences when he said: "you actually feel like out of place really...So, it was like we [men's basketball team] were the outcasts of the group...Wherever we went we were the basketball team." The CRT tenet of interest convergence provides a possible explanation for this disparate enrollment. Particularly, the primary interest of these PWIs is to field successful athletic programs that generate revenues for the athletic department and increase institutional visibility, which justifies their recruitment of talented Black male student athletes (Donnor, 2005). In exchange, Black male student athletes are afforded an opportunity to participate in intercollegiate athletics. The problem within this arrangement lies in the fact that the interest convergence is centered on athletics with little to no regard for Black male student athletes' academic or personal development. In the current study, this overemphasis on athletics over academic and personal development led to negative educational experiences for the participants and motivated them to transfer to a HBCU. These findings support previous studies, which found the overemphasis on athletics over academics contributed to poor academic outcomes for African American male student athletes (e.g., lower GPAs, decreased academic engagement, lower graduation rates, under preparation for post-college careers, etc.; Beamon, 2008; Beamon \& Bell, 2006; Benson, 2000).

Additional reasons for why Black male student athletes chose to transfer from a PWI to a HBCU were their encounters with various forms of racism. These findings are consistent with the CRT tenet that purports racism is a pervasive and unchangeable reality of U.S. society (Bell, 1992). Each participant expressed experiencing a level of cultural dissonance at the PWI they previously attended. A primary group responsible for these feelings of cultural dissonance was the faculty at the PWIs. Paul captured this sentiment when he described the difference between his interactions with professors at the major Division I PWI he attended and the HBCU in which he was currently enrolled. He explained how he felt a level of distrust at the PWI because his professors did not understand him when he provided them with a reason for why he had to miss class or did not do well on an assignment. He attributed this dissonance to the fact that he was a Black male student athlete at a PWI. These findings are contrary to Martin, Harrison, and Bukstein's (2010) findings that African American male student athletes at major Division I PWIs experienced positive relationships with their professors. Rather the participants' experiences echo Singer's (2005) findings that African American male student athletes' perceptions of differential treatment at PWIs 
reflected the cultural mistrust they felt toward the campus community at these institutions. In addition, these findings underscore the notion that the quality of Black male student athletes' experiences and academic performance in college is largely predicated on the nature and quality of their interactions with faculty (Benson, 2000; Comeaux \& Harrison, 2007; Harrison, Comeaux, and Plecha, 2006; Martin et al., 2010).

A possible explanation for the cultural dissonance between Black male student athletes and PWIs is the result of negative perceptions held by faculty regarding Black male student athletes' intellectual capabilities and their primary purpose at the institution. According to CRT, racism is deeply engrained in the U.S. society (Bell, 1992). A longstanding racist myth associated with Black males is the notion that they are intellectually inferior, yet physically superior (Hoberman, 1997). Related to faculty perceptions of Black student athletes at PWIs, Comeaux (2010b) found that faculty at a PWI were more likely to view the academic accomplishments of Black student athletes as abnormal, whereas these same accomplishments were viewed as an expectation for White student athletes. Along the same lines, Beamon \& Bell (2006) found that Black student athletes at a PWI were more likely to be suspended for academic reasons even though White student athletes were more likely to earn failing grades. The authors suggested the low academic expectations of faculty and racism were possible explanations for this trend of disparate treatment. Given the fact, a majority of the faculty at PWIs are White, Black male student athletes may perceive the differential treatment they receive from faculty as a form of racism particularly within an educational environment where they experience other forms of racial microaggressions (Solórzano, Ceja, \& Yosso, 2000). Racial microaggressions are subtle actions (verbal, behavioral, or environmental) that communicate negative messages toward a target group of people within a given context (Sue et al., 2007). In the context of faculty-Black male student athlete interactions at PWIs, racism does not need to be explicit or intentional in nature; it only needs to reinforce the values, beliefs, and assumptions embedded within a systemically racist society (e.g., U.S.) or environment (e.g., PWI; Ladson-Billings \& Tate, 1995).

In a related vein, participants in the current study also highlighted their encounters with racial microassaults from their peers at the PWIs they attended (Sue et al., 2007). A racial microassault is an "explicit racial derogation characterized by a verbal or nonverbal attack meant to hurt the intended victim through name calling, avoidant behavior, or purposeful discriminatory actions" (Sue et al., 2007, p. 274). For example, each participant described an experience with avoidant behavior from their nonteammate peers at the PWIs they attended, which contributed to their feelings of isolation, resentment, and frustration. Michael accurately described the group's feeling about their encounters with avoidant behavior when he said: “... after practice it was just go home. It wasn't like you had some kind of bond with the other students at school or whatever. But, it was just it was like that." Similarly, Melendez (2008) found that Black male student athletes at a PWI felt a "stigma" placed on them by their professors and peers whereby they were stereotyped based on their race and athletic status and therefore socially isolated (p. 438). As a result, the findings from the current study reinforce the notion that race and racism remain mitigating factors in the quality of Black male student athletes' educational experiences at PWIs (Beamon, 2008; Benson, 2000; Melendez, 2008; Oseguera, 2010; Singer, 2005, 2008, 2009) 
In addition to covert forms of racism, findings also revealed participants were introduced to the Whiteness as property norm at the PWIs they attended (Harris, 1993). A prime example of the enforcement of the Whiteness as property norm was evident in Brian's experience at the student center at the JUCO PWI he attended. He described how he and his Black teammates were told they could not play video games in the student center, which was a privilege that was afforded to a group of White students. Regardless of the intention of the institutional staff member who enforced this policy, Brian interpreted this action as a form of racial discrimination because it was consistent with other negative encounters he experienced at the institution based on his race. In this instance, the institution was communicating to Brian and his teammates that they were denied the rights of use and enjoyment of status property at the PWI because of their race (Harris, 1993). It is important to note that Brian's interpretation of this event was not a result of an isolated situation, but a byproduct of his collective experiences with racial microaggressions at the PWI (Solórzano et al., 2000; Sue et al., 2007).

Regarding research question two, the participants' responses about their experiences at a HBCU serve as vital (counter)stories against dominant narratives, which tend to ignore the voices of Black male student athletes who attend these institutions (Delgado \& Stefanic, 2001; Solórzano \& Yosso, 2002). In contrast, to dominant narratives that suggest HBCUs are ill-equipped to meet the educational needs of Black students in the 21st century (Riley, 2010), findings from the current study highlighted key institutional practices at a HBCU that enhanced Black male student athletes' academic engagement and persistence. In particular, the participants' (counter)stories described how the professors at the HBCU demonstrated an ethic of care toward them and supported their holistic development rather than simply focusing on their athletic abilities. Moreover, the campus climate at the HBCU reflected a nurturing and supportive environment that fostered positive educational outcomes for Black male student athletes. Thus, the (counter)stories support previous research which found these institutions to be effective learning environments for Black male student athletes' to experience positive educational outcomes (Charlton, 2011; Cooper \& Hawkins, 2012).

\section{Conclusion}

In conclusion, the findings from the current study reiterate the notion that HBCUs continue to serve as positive educational environments for Black male student athletes (Charlton, 2011; Cooper \& Hawkins, 2012). A significant influence on the participants' college experiences was their relationships with their professors. These findings support Cooper and Hawkins' (2012) Nurturing Community Hypothesis $(\mathrm{NCH})$, which suggested positive outcomes for Black male student athletes occur when they experience an educational environment that actively promotes their holistic development. The professors at SSU fostered a transformational educational experience for the participants by demonstrating a genuine interest in their overall well-being and success beyond athletics.

Moreover, the findings from the current study echo previous studies, which applied CRT to the examination of Black male student athletes' experiences in college and highlighted how the campus climates at many PWIs present significant challenges for Black male student athletes' overall development (Bimper et al., 
2012; Comeaux, 2010b; Donnor, 2005; Harper, 2009; Singer, 2005). Specifically, the frequent encounters with covert racism via racial microassaults such as avoidant behavior by faculty and peers and less frequent encounters with overt racism such as differential treatment from faculty and staff contributed to the participants' feelings of rejection and isolation at the PWIs they attended (Solórzano et al., 2000; Sue et al., 2007). Conversely, the transfer effect of attending a HBCU resulted in positive perceptions of institutional support and strong peer relationships. The nurturing environment at the HBCU valued the participants' sociocultural backgrounds, acknowledged their unique needs, and supported their holistic development.

\section{Limitations}

The current study contained several limitations including the small sample size, data collection methods and analyses, the focus of the study, and the length of time associated with the study. The use of purposeful sampling as opposed to a random sampling approach limited the transferability findings. The use of a single focus group and two individual interviews limited the researcher's ability to investigate a range of topics related to the phenomena (e.g., precollege background, athletic skill levels, academic history, etc.) because the topics discussed were limited to the semistructured questions and the topics discussed by the participants. The focus of the study was limited to the participants' reasons for choosing to transfer from a PWI to a HBCU and their perceptions of their college experiences at a HBCU. Lastly, the qualitative case study design only captured the participants' perceptions at one point in time, thus limited the researcher's ability to identify longitudinal patterns and outcomes.

\section{Implications for Policy and Practice}

Findings from the current study provide insight into the experiences of Black male transfer student athletes who attended a PWI and a HBCU. The participants' stories offer useful information to all educational stakeholders who are committed to cultivating positive outcomes for Black male student athletes. One primary recommendation for improving the educational experiences and outcomes of Black male student athletes is to create more awareness among faculty about issues regarding the experiences of minority students. Regular forums should be held on an institutional basis to make available to faculty information such as findings from the current study and similar studies to inform them about various ways they contribute to the cultivation of unwelcoming educational environments. In addition, within these forums conversations can be held between faculty, administrators, staff, and students about effective strategies for addressing such pervasive issues. For example, a task force or committee including a group of students, faculty, administrators, and staff could be assigned the responsibility of identifying the needs of different groups on campus (e.g., Black male student athletes), present their findings to faculty across the campus, and actively be involved in the implementation of these programs and services to create culturally responsive and positive campus climates for all students.

Another recommendation for addressing the challenges facing transfer student athletes is to strengthen the communication and collaboration between the NCAA 
and JUCO/community colleges. Harper (2009) used the interest convergence principle of CRT to explain how community colleges and Black male transfer student athletes could mutually benefit from higher rates of student athletes transferring to four-year institutions. Along the same lines, all postsecondary institutions could benefit from identifying and disseminating best practices related to positive transitional outcomes for transfer student athletes. Increasing communication across all divisions and institutional types could lead to better programs and services designed to enhance student athletes' college experiences, academic achievement, and post college career outcomes. Similar to the previous recommendation, this communication could involve the creation of a committee designed to identify key challenges facing transfer student athletes and establish effective programs and services to facilitate increased transfer and graduation rates.

Individual institutions should also create programs that provide Black male student athletes with an outlet to discuss issues of racism with faculty and nonfaculty mentors and their peers. Participants in the current study expressed how a primary reason they chose to transfer from a PWI was the perception that they would be accepted and supported at a HBCU rather than be isolated and stigmatized. Even though, PWIs cannot duplicate the sociocultural uniqueness of HBCUs, they can offer culturally responsive programs designed to increase Black male student athletes' sense of belonging. For example, at the University of Texas, the Longhorn Center for Academic Excellence under the guidance of Dr. Leonard Moore sponsors programs such as the African American Male Research Initiative (AAMRI) and Utransition. The AAMRI is a program designed to increase Black male students' educational experiences, achievement, and psychosocial development at the secondary and postsecondary levels (UT Division of Diversity and Community Engagement, 2013). In addition, the Utransition program provides a plethora of resources to transfer students with a variety of services such as academic support, social/cultural/recreational activities, graduate school preparation, and American Council on Education (ACE) workshops (UT Division of Diversity and Community Engagement, 2013). Building on the success of programs such as the AAMRI and Utransition, postsecondary institutions could create programs and services specifically designed to address the unique needs of minority populations such as Black male transfer student athletes. As such, minority students could benefit from a sense of empowerment and collective identity with peers and mentors who understand the challenges they face and demonstrate an interest in their successful transition to college and postcollege success.

\section{Future Research}

The research on transfer student athletes' experiences at two-year institutions as well as four-year institutions is scarce. As a result, future research should examine the experiences and developmental outcomes of this cohort of student athletes across institutional settings (e.g., two-year institutions, four-year institutions, divisional classification (I, II, and III), private, public, HBCUs, PWIs, etc.). Future studies should also compare the developmental outcomes of transfer student athletes to nontransfer student athletes. Along the same lines, future research could expand the sample of the study to include a diverse group of participants (e.g., race, gender, 
sport participation, academic classification, precollege background, etc.) to examine common patterns and differences in their experiences and outcomes. Future research should also include the perspectives of institutional faculty, administrators, and staff on the performance of transfer student athletes. Lastly, a longitudinal study of a group of transfer student athletes from their initial college enrollment through postcollege experiences would be beneficial to gaining a deeper understanding of transfer student athletes' experiences in college.

\section{Notes}

1. The researcher uses the term "Black" instead of "African American" to describe the racial group rather the ethnic group (Humes, Jones, \& Ramirez, 2011). The term "African American" will only be used when cited from specified reference. Definitions retrieved from Humes, K. R., Jones, N. A., \& Ramirez, R. R. (2011). Overview of Race and Hispanic origin: 2010. Retrieved from http://www.census.gov/prod/cen2010/briefs/c2010br-02.pdf

2. The term researcher refers to the first author.

3. Pseudonyms were applied for all participants to preserve their anonymity.

4. A JUCO school is a two-year institution of higher education in the U.S., also referred to as a community college, that students can enroll to earn an associate's degree and/or transfer to a four-year institution upon completion.

5. Pseudonyms were applied for all school references to preserve the institution's anonymity.

6. In an effort to provide anonymity of the institutions and participants used for this study, pseudonyms were assigned to each respective institution.

\section{References}

Agyemang, K., Singer, J.N., \& DeLorme, J. (2010). An exploratory study of black male college athletes' perceptions of race and athlete activism. International Review for the Sociology of Sport, 45(4), 419-435. doi:10.1177/1012690210374691

Allen, W.R. (1992). The color of success: African American college students outcomes at predominantly White and historically Black public colleges and universities. Harvard Educational Review, 62(1), 26-44.

Allen, W.R., \& Jewel, J.O. (2002). A backward glance forward: Past, present, and future perspectives on historically Black colleges and universities. Review of Higher Education, 25(3), 241-261. doi:10.1353/rhe.2002.0007

Auerbach, N., \& Prisbell, E. (2012). College basketball's free agency era. Retrieved on June 1, 2013 from http://www.usatoday.com/story/sports/ncaab/2012/11/06/ncaa-menscollege-basketball-transfers/1679115/

Beamon, K., \& Bell, P.A. (2006). Academics versus athletics: An examination of the effects of background and socialization on African American male student. The Social Science Journal, 43, 393-403. doi:10.1016/j.soscij.2006.04.009

Beamon, K.K. (2008). "Used goods": Former African American college student-athletes' perception of exploitation by Division I universities. The Journal of Negro Education, 77(4), 352-364.

Bell, D.A. (1980). Brown v. Board of Education and the interest convergence dilemma. Harvard Law Review, 93, 518-533. doi:10.2307/1340546

Bell, D.A. (1992). Faces at the bottom of the well: The permanence of racism. New York, NY: Basic Books. 
Benson, K. (2000). Constructing academic inadequacy: African American athletes' stories of schooling. The Journal of Higher Education, 71(2), 223-246. doi:10.2307/2649249

Biddle, S., Markland, D., Gilbourne, D., Chatzisarantis, N., \& Sparkes, A. (2001). Research methods in sport and exercise psychology: Quantitative and qualitative issues. Journal of Sports Sciences, 19, 777-809. PubMed doi:10.1080/026404101317015438

Bimper, A.Y., Harrison, L., \& Clark, L. (2012). Diamonds in the rough: Examining a case of successful Black male student athletes in college sport. The Journal of Black Psychology, 1-24.

Charlton, R. (2011). The role of policy, rituals, and language in shaping an academically focused culture in HBCU athletics. Journal of Issues in Intercollegiate Athletics, 4, $120-148$.

Comeaux, E. (2010a). Mentoring as an intervention strategy: Toward a (re)negotiation of first year student-athlete role identities. Journal for the Study of Sports and Athletes in Education, 4(3), 257-276. doi:10.1179/ssa.2010.4.3.257

Comeaux, E. (2010b). Racial differences in faculty perceptions of collegiate studentathletes' academic and post-undergraduate achievement. Sociology of Sport Journal, 27, 390-412.

Comeaux, E., \& Harrison, C.K. (2007). Faculty and male student-athletes: Racial differences in the environmental predictors of academic achievement. Race, Ethnicity and Education, 10(2), 199-214. doi:10.1080/13613320701330726

Cook, A.E. (1995). Beyond critical legal studies: The reconstructive theology of Dr. Martin Luther King. In K. Crenshaw, N. Gotanda, G. Peller, \& K. Thomas (Eds.), Critical race theory: The key writings that formed the movement. New York, NY: The New Press.

Cooper, J.N. (2012). Personal troubles and public issues: A sociological imagination of Black athletes' experiences at predominantly White institutions in the United States. Sociology Mind, 2, 261-271. doi:10.4236/sm.2012.23035

Cooper, J.N., \& Hawkins, B. (2012). A place of opportunity: Black male student athletes' experiences at a Historically Black University. Journal of Intercollegiate Sport, 5, $170-188$.

Crenshaw, K. (1995). Mapping the margins: Intersectionality, identity politics, and violence against women of color. In K. Crenshaw, N. Gotanda, G. Peller, \& K. Thomas (Eds.), Critical race theory: The key writings that formed the movement. New York, NY: The New Press.

Dalton, H.L. (1995). The clouded prism: Minority culture of the critical legal studies movement. In K. Crenshaw, N. Gotanda, G. Peller, \& K. Thomas (Eds.), Critical race theory: The key writings that formed the movement. New York, NY: The New Press.

Decuir, J.T., \& Dixson, A.D. (2004). So when it comes out, they aren't that surprised that it is there. Using critical race theory as a tool of analysis of race and racism in education, 33, 26-31. Retrieved on May 2, 2013 from http://www.aera.net/uploadedFiles/ Journals_and_Publications/Journals/Educational_Researcher/Volume_33_5/06ERv33n5_DeCuir-Dixson.pdf

Delgado, R., \& Stefanic, J. (2001). Critical race theory: An introduction. New York, NY: New York University Press.

Denzin, N.K., \& Lincoln, Y.S. (2005). The sage handbook of qualitative research (3rd ed.). Thousand Oaks, CA: Sage Publications.

Donnor, J.K. (2005). Towards an interest-convergence in the education of African-American football student-athletes in major college sports. Race, Ethnicity and Education, 8(1), 48. doi:10.1080/1361332052000340999

Gallien, L.B., Jr. (2005). The historical and cultural context of educating African American college students. In L.B. Gallien, Jr. \& M.S. Peterson (Eds.), Instructing and mentoring the African American college student: Strategies for success in higher education (pp. 3-14). Boston, MA: Pearson Education, Inc.

Gratton, C., \& Jones, I. (2010). Research methods for sport studies (2nd ed.). New York, NY: Routledge. 
Harper, S.R. (2009). Race, interest convergence, and transfer outcomes for Black male student-athletes. New Directions for Community Colleges, 147, 29-37. doi:10.1002/cc.375

Harris, O. (1993). Whiteness as property. Harvard Law Review, 106(8), 1709-1791. doi:10.2307/1341787

Harrison, C.K., Comeaux, E., \& Plecha, M. (2006). Faculty and male football and basketball players on university campuses: An empirical investigation of the "intellectual" as mentor to the student-athlete. Research Quarterly for Exercise and Sport, 77, 277-284. PubMed

Harrison, L., Jr., Sailes, G., Rotich, W.K., \& Bimper, A.Y., Jr. (2011). Living the dream or awakening from the nightmare: race and athletic identity. Race, Ethnicity and Education, 14(1), 91-103. doi:10.1080/13613324.2011.531982

Harrison, C.K., Stone, J., Shapiro, J., Yee, S., Boyd, J.A., \& Rullan, V. (2009). The role of gender identities and stereotype salience with the academic performance of male and female college athletes. Journal of Sport and Social Issues, 33(1), 78-96. doi:10.1177/0193723508328902

Hawkins, B. (2010). The new plantation: Black athletes, college sports, and predominantly White institutions. New York, NY: Palgrave-MacMillan.

Hildenbrand, K., Sanders, J.P., Leslie-Toogood, A., \& Benton, S. (2009). Athletic status and academic performance and persistence at a NCAA division I university. Journal for the Study of Sports and Athletes in Education, 3(1), 41-58. doi:10.1179/ ssa.2009.3.1.41

Hoberman, J. (1997). Darwin's athletes: How sport has damaged Black America and preserved the myth of race. Boston, MA: Houghton Mifflin Company.

Hodge, S.R., Bennett, R.A., III, \& Collins, F.G. (2013). Historically Black colleges and universities' athletes and sport programs: Historical overview, evaluations, and affiliations. In D. Brooks \& R. Althouse (Eds.), Racism in College Athletics (pp. 63-104). Morganton, WV: Fitness Information Technology.

Humes, K.R., Jones, N.A., \& Ramirez, R.R. (2011). Overview of Race and Hispanic origin: 2010. Retrieved on June 1, 2013 from http://www.census.gov/prod/cen2010/briefs/ c2010br-02.pdf

Keim, M.C., \& Strickland, J.M. (2004). Support services for two-year college studentathletes. College Student Journal, 38(1), 36-43.

Kitzinger, J. (1995). Introducing focus groups. BMJ (Clinical Research Ed.), 311, 299-302. PubMed doi:10.1136/bmj.311.7000.299

Kornspan, A.S., \& Etzel, E.F. (2001). The relationship of demographic and psychological variables to career maturity of junior college student-athletes. Journal of College Student Development, 42(2), 122-132.

Ladson-Billings, G., \& Tate, W. (1995). Toward a critical race theory of education. Teachers College Record, 97(1), 47-68.

Lawrence, C.R., III. (1995). The id, the ego, and equal protection: Reckoning with unconscious racism. In K. Crenshaw, N. Gotanda, G. Peller, \& K. Thomas (Eds.), Critical race theory: The key writings that formed the movement (pp. 253-257). New York, NY: The New Press.

Lawrence, S.M., Harrison, C.K., \& Stone, J. (2009). A day in the life of a male college athlete: A public perception and qualitative campus investigation. Journal of Sport Management, 23, 591-614.

Martin, B.E., \& Harris, F., III. (2006). Examining productive conceptions of masculinities: Lessons learned from academically driven African American male student-athletes. Journal of Men's Studies, 14, 359-378. doi:10.3149/jms.1403.359

Martin, B., Harrison, C.K., \& Bukstein, S. (2010). "It takes a village" for African American male scholar-athletes. Journal for the Study of Sports and Athletes in Education, 4, 277-295. doi:10.1179/ssa.2010.4.3.277 
Martin, B.E., Harrison, C.K., Stone, J., \& Lawrence, S.M. (2010). Athletic voices and academic victories: African American male student-athlete experiences in the Pac Ten. Journal of Sport and Social Issues, 34(2), 131-153. doi:10.1177/0193723510366541

Melendez, M. (2008). Black football players on a predominantly white college campus: Psychological and emotional realities of the Black college athlete experience. The Journal of Black Psychology, 34, 423-451. doi:10.1177/0095798408319874

Matsuda, M. (1995). Looking to the bottom: Critical legal studies and reparations. In K. Crenshaw, N. Gotanda, G. Peller, \& K. Thomas (Eds.), Critical race theory: The key writings that formed the movement. New York, NY: The New Press.

NCAA. (2011a). Trends in academic success rates and federal graduation rates at NCAA Division II institutions. Retrieved on March 22, 2013 from http://www.ncaa.org/wps/ $\mathrm{wcm} / \mathrm{connect/public/NCAA/PDFs/2011/Trends+in+Academic+Success+Rates+and+}$ Federal+Graduation+Rates+at+NCAA+Division+II+Institutions

NCAA. (2011b). Trends in academic success rates and federal graduation rates at NCAA division II institutions. Retrieved on March 22, 2013 from http://www.ncaa.org/wps/ $\mathrm{wcm} / \mathrm{connect} / \mathrm{public} / \mathrm{NCAA} / \mathrm{PDFs} / 2011 /$ Trends+in+Academic+Success+Rates+and+ Federal+Graduation+Rates+at+NCAA+Division+II+Institutions

NCAA. (2012a). NCAA Transfer Guide. Retrieved on March 22, 2013 from http://www. ncaapublications.com/productdownloads/TGONLINE2012.pdf

NCAA. (2012b). National and sport-group APR averages, trends, and penalties. Retrieved on March 22, 2013 from http://www.ncaa.org/wps/wcm/connect/public/ncaa/pdfs/2012/ apr+2012+trends

NCAA. (2013). Get the facts about transfers. Latest News. Retrieved on March 22, 2013 from http://www.ncaa.org/wps/wcm/connect/public/NCAA/Resources/Latest+News/2012/ May/Get+the+facts+about+transfers

Oseguera, L. (2010). Success despite the image: How African American male student-athletes endure their academic journey amidst negative characterizations. Journal of the Study of Sports in Education, 4, 297-324.

Pascarella, E.T., Truckenmiller, R., Nora, A., Terenzini, P.T., Edison, M., \& Hagedorn, L.S. (1999). Cognitive impacts of intercollegiate athletic participation: Some further evidence. The Journal of Higher Education, 70(1), 1-26. doi:10.2307/2649116

Pascarella, E.T., \& Terenzini, P.T. (2005). How college affects students: a third decade of research. San Francisco, CA: Jossey-Bass.

Patton, M.Q. (2002). Qualitative research and evaluation methods (3rd ed.). Thousand Oaks, CA: Sage Publications.

Potuto, J.R., \& O'Hanlon, J. (2006). National study of student-athletes regarding their experiences as college students. Retrieved on June 1, 2013 from http://fs.ncaa.org/Docs/ library/research/student-athlete_experiences/2006/2006_s-a_experience.pdf

Riley, J. (2010). Black colleges need a new mission. Retrieved on September 12, 2013 from http:// www.thurgoodmarshallfund.net/images/pdf/newsarticles/blackcollegesnewmission.pdf

Roulston, K. (2010). Reflective interviewing: A guide to theory \& practice. Thousand Oaks, CA: Sage Publications.

Ryan, G.W., \& Bernard, H.R. (2000). Data management and analysis methods. In N.K. Denzin \& Y.S. Lincoln (Eds.), Handbook of qualitative research (2nd ed., pp. 769-802). Thousand Oaks, CA: Sage Publications.

Scanlan, T.K., Ravizza, K., \& Stein, G. (1989). An in-depth study of former elite figure skaters: II. Sources of enjoyment. Journal of Sport \& Exercise Psychology, 11, 65-82.

Scanlan, T.K., Stein, G., \& Ravizza, K. (1991). Sources of stress in elite figure skaters. Journal of Sport \& Exercise Psychology, 13, 103-120.

Sellers, R.M. (1992). Racial differences in the predictors for academic achievement of student-athletes in Division I revenue producing sports. Sociology of Sport Journal, $9(1), 48-59$. 
Shulman, J., \& Bowen, W. (2001). The game of life: College sports and educational values. Princeton, NJ: Princeton University Press.

Singer, J.N. (2005). Understanding racism through the eyes of African-American male studentathletes. Race, Ethnicity and Education, 8(4), 365-386. doi:10.1080/13613320500323963

Singer, J.N. (2008). Benefits and detriments of African American male athletes' participation in a big - time college football program. International Review for the Sociology of Sport, 43, 399-408. doi:10.1177/1012690208099874

Singer, J.N. (2009). African American football athletes' perspectives on institutional integrity in college sport. Research Quarterly for Exercise and Sport, 80(1), 102-116. PubMed doi:10.1080/02701367.2009.10599534

Singer, J.N., Harrison, C.K., \& Bukstein, S. (2010). A critical race analysis of the hiring process for head coaches in NCAA college football. Journal of Intercollegiate Sport, 3, 270-296.

Solórzano, D., Ceja, M., \& Yosso, T. (2000). Critical race theory, racial microaggressions, and campus racial climate: The experiences of African American college students. The Journal of Negro Education, 69, 60-73.

Solórzano, D., \& Yosso, T. (2002). Critical race methodology: Counter-storytelling as an analytical framework for education research. Qualitative Inquiry, 8(1), 23-44. doi:10.1177/107780040200800103

Sue, D.W., Capodilupo, C.M., Torino, G.C., Bucceri, J.M., Holder, A.M.B., Nadal, K.L., \& Esquilin, M. (2007). Racial microaggressions in everyday life: Implications for clinical practice. The American Psychologist, 62, 271-286. PubMed doi:10.1037/0003066X.62.4.271

Tashakkori, A., \& Teddlie, C. (1998). Mixed methodology: Combining qualitative and quantitative approaches. Thousand Oaks, CA: Sage Publications.

Taylor, E., Gillborn, D., \& Ladson-Billings, G. (2009). Foundations of critical race theory in education. New York, NY: Routledge.

UT Division of Diversity and Community Engagement. (2013). African American male research initiative Retrieved on April 4, 2013 from http://ddce.utexas.edu/ academiccenter/aamri/

UT Division of Diversity and Community Engagement. (2013). Utransition Retrieved April 4, 2013 from http://ddce.utexas.edu/academiccenter/utransition/ 